To cite:

Waxell, Anders (2011). Life sciences and human capital: Jobless growth on specialised and local labour markets? Growth and Change, 42(3), pp. 231-260.

[Page numbers in printed version cited in brackets throughout the paper]

\title{
Life Sciences and Human Capital: Jobless Growth on Specialised and Local Labour Markets?
}

\begin{abstract}
ANDERS WAXELL
Centre for Research on Innovation and Industrial Dynamics (CIND), Department of Social and Economic Geography, Uppsala University,

P.O. Box 513,
\end{abstract}

SE-751 20 Uppsala, Sweden

\begin{abstract}
Policy makers and scholars often regard the life science industry in general, and bio-technology in particular, as an engine of future economic growth. The expectation is that growth in the industry will ultimately provide a major boost to national employment numbers. However, in this paper, I find that the Swedish life science industry (encompassing pharmaceutical, bio-technology, and medical technology firms) accounts for only a small proportion of total employment in Sweden. Given the recent discussion on jobless growth (i.e., economic growth without employment growth), it is here argued that focusing on employment is not necessarily the best policy approach to assessing the impacts of the life science industry on the overall economy. This paper maps and analyses the scope, structure, and geography of the life science industry and its workforce in Sweden using a unique set of data covering approximately 1,200 firms and 53,000 employees. The industry's workforce has education and income levels significantly higher than national averages, and is heavily concentrated in larger metropolitan areas and major university cities. Despite employing relatively few people and being more or less dependent on the existence and success of a few major pharmaceutical firms, the industry may still have a significant impact on the national economy by engendering high levels of education, income, and export revenues, particularly in specific regions.
\end{abstract}




\section{INTRODUCTION}

Since the post-war period, the world economy has become ever more globalised and has undergone considerable structural changes. While labour-intensive production is increasingly being relocated to low-cost countries, [end of p. 231] primarily in Southeast Asia, Organisation for Economic Co-operation and Development (OECD) countries, such as Sweden, are relying more on knowledge-intensive service production to compete in the global market. The cornerstones of this "new" knowledge-based economy are best described in terms of concepts such as innovation, research and development (R\&D), design, culture, venture capital, marketing, and, in particular, human capital. Although new communications technologies are helping to bring the farthest reaches of the world closer together, reducing the constraints of distance, local and regional milieus are paradoxically receiving greater recognition as important arenas fostering academic excellence, industrial innovation, and competitive advantage. Recent studies in economic geography have come to focus on localisation economies and industrial agglomerations (cf. Cooke and Morgan 1998; Cooke, Uranga, and Etxebarria 1997; Maskell and Malmberg 1999; Porter 1990, 2000; Thrift and Amin 1994) and, in particular, on how specialised knowledge and skills embedded in local labour markets are formed and contribute to industrial transformation and growth (Almeida and Kogut 1999; Combes and Duranton 2006; Henry and Pinch 2000; Power and Lundmark 2004; Waters and Lawton Smith 2008; Waxell and Malmberg 2007). In the wake of the technological developments of recent decades, new industries are emerging and older ones are being transformed. In this context, the life science industry-notably pharmaceuticals, bio-technology, and medical technology — is recognised by both policy makers and researchers as a potential future "growth industry" (see CEC 2002; Ernst and Young 2007; OECD 2007; OECD Observer 1999). It is often argued that research and entrepreneurship related to the life sciences will foster growth by creating new and rising employment opportunities.

By performing a descriptive analysis, this study discusses and helps form a detailed image of the life science industry and its prerequisites as a growth industry, in particular as an "engine of employment growth." The empirical evidence presented here indicates that firms operating in the life science industry represent only a small share of Sweden's total employment. In a situation in which fewer and fewer individuals are required to produce economic growth, pertinent issues are who actually works in these emerging industries and how the economic geography of these industries is characterised. In recent years, this has contributed to an emerging growth policy discussion concerning the phenomenon of "jobless growth," i.e., national economic growth unaccompanied by an increasing number of employment opportunities (cf. Baily and Lawrence 2004; Bhalotra 1998; Dasgupta and Singh 2005; Nutek 2006; Onaran 2008; Peck and Theodore 2007). In contrast to a view of national growth based on employment growth, the study aims to highlight other factors (especially human capital) that may contribute to [end of p. 232] long-term national economic growth. Here, human capital is understood as individuals having specialised skills built from unique resources embedded in specific, local labour markets. 
Entrepreneurship in the Swedish life science sector has been analysed in previous research (e.g., Dolk and Sandström 2007; Johnreden and Tydén 2005). Unlike previous research, the present study is based on a unique and comprehensive mapping of active firms in the life science industry in 2005. Attached to this is a unique set of individualbased data from the PLACE and LOUISE databases, which include all individuals of working age in Sweden. The study applies a workforce perspective and provides a detailed examination of the Swedish life science industry. More specifically, the study aims to understand the structure and composition of the life science industry by examining the human capital (defined as education, occupation, and income) and the geographical distribution and regional specialisation of the industry. The main question is to understand in what sense the life science industry could be viewed as a growth industry.

The study is structured as follows. In the section "Theoretical Framework," central concepts are introduced and human capital is discussed in relation to specialised, regional labour markets. This is followed by a discussion of knowledge as a location factor and the relationship between academia and the life science industry. The section "Method, Material, and Definitions" describes key variables, study material, and the execution of the study. In the following empirical sections, the structure, jobless growth, human capital, geographical distribution, and specialisation of the life science industry are described and analysed. This is followed by a summary and a concluding discussion.

\section{THEORETICAL FRAMEWORK: INDUSTRIAL TRANSFOR- MATION, HUMAN CAPITAL, AND GEOGRAPHY}

The life sciences-understood as the research and application areas in which technological principles are used to solve medical and biological problems, and vice versa - as a field of research and industry, has emerged through dynamic processes in which both new and prior knowledge are brought together across various disciplines and fields of knowledge. This is also how industrial transformation occurs: a struggle between new and old leading to change, which in turn stimulates economic development. What drives this change is often linked to technological change, or innovativeness, and/or organisational changes. This means that products and modes of production are constantly evolving through an interplay between firms, their workers, and their customers (see Dahmén 1980; Lundvall 1992). In recent decades, changes in the global economy have led to a structural shift in which global competition has become increasingly obvious. For [end of p. 233] countries such as Sweden, this has meant a growing political interest in innovation, $R \& D$, and new technology-oriented industries such as IT and bio-technology.

In other words, with a continued globalisation, it has become ever more important for firms to keep improving and upgrading, for example, their products, production 
processes, organisational structure, and knowledge handling. This has also led to increasing local, regional, and national specialisation in which some industries have come to be agglomerated in specific regional or local milieus (Cooke and Morgan 1998; Cooke, Uranga, and Etxebarria 1997; Maskell and Malmberg 1999; Porter 1990, 2000; Thrift and Amin 1994). This stands in marked contrast to a previous contradictory view in which firms, especially multinationals, have become regarded as "placeless." In the knowledge-based economy, proximity and access to knowledge and skills (e.g., research and other state-of-the-art technology) are key driving forces underlying economic development. Considerable research interest is being paid to how human capital and labour form advantageous production factors and how they contribute to economic development and growth in a country or in certain places. It has become increasingly clear that skills and competencies, and workforce mobility, rather than labour costs, are contributing to spatial agglomeration and spatial specialisation (see Almeida and Kogut 1999; Henry and Pinch 2000; Power and Lundmark 2004).

\section{Human capital and jobless growth}

Local, regional, and national economic growth are dependent on education, human capital, knowledge, and skills, and this reality is obvious in the regional policy of the European Union (EU) and the Treaty of Lisbon (see DS 2007:48 2007). This can be seen as a long-term result of the structural changes of recent decades in the labour market, which is now largely characterised by weaker and more insecure terms of employment (raising the demand for both employer and employee flexibility), continuous competence upgrading, and the decentralisation of the union (see Magnusson 1999, 2006a).

During the recent decade, the changing labour market conditions have come to stimulate a debate on jobless growth, a phenomenon visible in employment statistics in advanced, as well as developing, economies in which increasing rates of growth in production and trade is not accompanied by a similar growth in new job opportunities (see Bhalotra 1998; Dasgupta and Singh 2005; Nutek 2006; Onaran 2008). In this context, economic growth will not reduce previous high levels of unemployment in certain industries or economies. In relation to economic recession, this is also paralleled by the phenomenon of "jobless recoveries" evident, for example, in the U.S. after the turn of the millennium (cf. Baily and Lawrence 2004; Peck and Theodore 2007). Some of the explanations of the causes of jobless growth is linked to increasing global competition, changing labour market structures and flexible employment situations (with, for example, a [end of p. 234] growing temporary staffing industry), the shift to a service economy, increasing wages, and the fact that more individuals are studying for longer periods and to a greater age. It is argued that jobless growth may also have a geographical impact and create greater differences between weak and strong regions. The human capital of the workforce and its geographical dimension and composition are key growth-generating resources affecting growth both regionally and nationally. 
Human capital had already been recognised as a key resource within the firm by Penrose (1959) in The Theory of the Growth of the Firm, which emphasises the importance of the skills, abilities, and resources of individual workers or in management. Skills and knowledge are also regarded as a form of capital (see Becker 1962; Lucas 1988; Schultz 1995). Such capital is often associated with skills that people acquire through training and experience, which in turn stimulate, for example, critical thinking, learning strategies, managerial skills, and equipment maintenance (Scott 2009). According to Barney (1991:101), this can be summarised as follows: "Human capital resources include the training, experience, judgment, intelligence, relationships, and insight of individual managers and workers in a firm." Human capital has, in this sense, become operationalised and measured in terms of numerical variables, such as education level and income (it is here assumed that an individual having more human capital also has a higher income), and in terms of specific educations and occupations, often linked to the term "learning by doing" (see Becker 1962; Lucas 1988; Mankiw, Romer, and Weil 1992).

Thus, human capital is here understood as individuals having specialised skills built from unique resources embedded in specific, local labour markets. Specific competencies are, in turn, based on experience perceived on social, professional, and educational terms. In a knowledge-based economy, it is important to have access to individuals who possess key competencies important for creating and sustaining innovativeness.

\section{Geography, agglomeration, and specialised labour markets}

In recent years, there has been a major research interest in local labour markets and the mobility of specialised labour (Almeida and Kogut 1999; Combes and Duranton 2006; Henry and Pinch 2000; Mattsson 2007; Power and Lundmark 2004; Waters and Lawton Smith 2008; Waxell 2005; Waxell and Malmberg 2007).

Having access to specialised labour embedded in a specific place and to a particular industry or type of activity was something that Marshall (1920/1960) had long ago identified as a key prerequisite for the emergence and evolution of clusters, or what he termed "industrial districts." In his argument, close cooperation between the core industry and its suppliers (both spatially and in terms of business) would, over time, pave the way for the evolution of a specialised [end of p. 235] knowledge and competence base that would be hard to copy elsewhere. In this sense, knowledge is regarded as an increasingly important resource and, as such, as a location factor that has come to surpass, or at least complement, previous more traditional and natural location factors (resources related to, e.g., raw materials, land, and harbour access). High-tech firms, such as those in the life sciences, have instead tended to locate near knowledgeintensive milieus and near universities and other research-related organisations (Audretsch 2001; Powell et al. 2002). Technology development and competitiveness are stimulated in locations where there is a good supply of quality research and 
education, well-functioning infrastructure, services, and complementary and specialised service providers, and a favourable labour market structure (see Magnusson 2006b).

Viewed from an economic-geographic perspective, local and regional milieus are important arenas in which relationships between public and private actors are created and maintained over time. Although embedded, these relationships should not be regarded as geographically bound or restricted to local locations, but may extend and cut across several geographic scales, both local and global. All interactions and knowledge transfer between actors are therefore set in a geographical context and performed by individuals or collectives (e.g., firms) that are spatially anchored or embedded. Knowledge diffusion is thus not a universal phenomenon that has the same outcome regardless of where it takes place. For example, this is explained by institutional and cultural differences that may well be territorially defined. Geographic proximity may, in addition, contribute, for example, to increased personal (i.e., faceto-face) interaction, short cognitive distances, linguistic commonalities, and trust between actors based on shared understanding, facilitating quick comparison, and other types of observation (Gertler 2003; Malmberg and Maskell 2002; Storper andVenables 2004). Moreover, if regional actors are part of a cluster (i.e., a concentration of firms and other actors in the same or related industries), it is not only likely that interaction will be strengthened because of close proximity, but that a number of other spatially related advantages will follow that may also spill over and benefit other actors in the region. These advantages are related to reduced costs as a result of resource sharing (e.g., infrastructure); reduced transaction and transportation costs; the emergence of a local milieu in which innovation and learning are stimulated (i.e., a milieu in which there are common standards, conventions, and other supportive institutions that in turn facilitate the transfer of, for example, tacit knowledge); and the build-up of local, specialised labour markets in which knowledge and skills are shared (Malmberg 1998).

\section{Knowledge as a location factor: The relationship between academy and industry}

Life science serves as an interesting example of an industry relying on human capital, geographical location, and the quality or structure of local and [end of p. 236] regional milieus. Processes and relationships related to the industry have given rise not only to new scientific fields of study and cross-disciplinary collaborations but also to new industrial applications and emerging industries.

The relationship between public research and private profit-making interests has proved the basis for many studies of the dynamics of knowledge-intensive industries. Although interrelated, these studies can be roughly divided into two strands of research. One strand focuses on the link between academia and industry, while the other analyses the importance of geographical proximity for these relationships. As regards the first strand, collaborations and strategic alliances among actors in different spheres are considered to contribute to new business formation, innovation, and patenting (see Acs, Audretsch, 
and Feldman 1994; Jaffe 1989; Lee and Gaertner 1994; Mansfield 1995; Rothaermel, Agung, and Jiang 2007), not least in the life sciences (Bagchi-Sen 2007; Blumenthal et al. 1996; Deeds and Hill 1996; Dibner 1986). In the second strand, there is evidence that geographical proximity, or being part of a geographical cluster, is important for knowledge transfer between academia and industry (Coenen, Moodysson, and Asheim 2004; Cooke 2002; Feldman 2003; Feldman and Florida 1994; Klofsten and JonesEvans 1996; Powell et al. 2002; Stephan, Audretsch, and Hawkins 2000). According to Audretsch and Stephan (1996), several smaller and more research-oriented firms in the life science sector have been established through research networks that bridge the industrial-academic divide. Zucker, Darby, and Armstrong (1998) and Zucker, Darby, and Brewer (1998) also find support for the importance of geographically agglomerated knowledge, arguing that being located near universities and other knowledge sources increases productivity in many bio-technology firms. More specifically, they investigate and find evidence that "intellectual human capital" - defined as world-leading researchers in life science-related fields - is a main factor determining both the start-up and the location of new bio-technology-related companies. Local and regional milieus are also important for small and medium-sized firms in the industry. However, DeMartino, Reid, and Zygliodopoulos (2006) show that as firms grow and become increasingly international, the global arena tends to become more important than the local one.

\section{METHOD, MATERIAL, AND DEFINITIONS}

This study is based on unique individual-based data from the PLACE and LOUISE databases and includes all individuals employed by a life science-oriented firm in Sweden in 2002 and 2005. A life science firm is here defined as a firm that produces products or services that use technology principles to solve biological and medical problems, and vice versa. The term life science is mainly used to group activities in the sub-sectors of pharmaceuticals, bio-technology, and [end of p. 237] medical technology. However, more generally, industrial applications of life science-oriented activities are found in several broader sub-sectors such as health care, agriculture and food, environment and energy, and processing industries (e.g., the mining, chemical, and pulp and paper industries; see Audretsch 2001; Eliasson and Eliasson 1997; OECD Observer 1999; SIND 1991). In this study, firms in the life science industry are divided into six broader categories or sub-industries: bio-technology, pharmaceuticals, medical technology, diagnostics, contract research organisations, and miscellaneous firms in life sciencerelated services. ${ }^{1}$ Furthermore, the study mainly defines human capital in terms of education and income level. To identify the various knowledge and skill structures in

${ }^{1}$ These categories are largely based on an outline of the industry presented by Vinnova in the report "National and Regional Cluster Profiles" (Dolk and Sandström 2007; for a more in-depth discussion of bio-tech-related industries, see also Waxell 2005). [on p. 255] 
the industry, types of education and occupation are also analysed (see Becker 1962; Lucas 1988; Mankiw, Romer, and Weil 1992).

The studied population was generated from a unique and comprehensive mapping of the industry in $2005 .^{2}$ Several methods and sources were used to identify firms having a life science focus. Initially, firms were identified in a national public database (i.e., AffärsData) using the Swedish Standard Industrial Classification 2002 standard industrial classification. This method is problematic and fails in many cases to identify firms in new or emerging industries, such as in bio-technology and other life science-oriented activities (see Waxell 2009). Furthermore, the increasing production of services in the economy is complicating the process of classifying and identifying a number of activities. This is particularly evident in the life science industry, in which many firms are small (often self-employed owner/operators) or medium sized and specialise in researchrelated consultancy. The population in this study was complemented by identifying firms via a comprehensive mapping of the industry using several sources such as research reports, industry association and cluster initiative membership lists, and trade journals. To link individuals to the life science firms identified in the mapping, registry data from the PLACE and LOUISE databases were used. These databases contain data on employment, education, and income and cover all individuals in Sweden aged 16 and above (see Statistics Sweden 2002). Because of the detailed nature of the information contained in the database, all data on individuals and organisations are anonymous. The material in the present study is based on data from 2002 and 2005. In total, 53,169 individuals in 1,230 firms were found. ${ }^{3}$

Although this study focuses on firms, the importance of viewing and analysing the life science industry from a broader industrial systems perspective is nevertheless central for understanding industrial transformation and growth. This means that the life science cluster or industrial system, as distinct from life science firms, also includes parts of the public research and educational system (e.g., [end of p. 238] universities and colleges), government agencies and research institutions, private research organisations and foundations, and parts of the health-care sector (see Waxell and Malmberg 2007).

\footnotetext{
${ }^{2}$ The population was the result of mapping performed by Intersecta AB in 2005. [on p. 255]

${ }^{3}$ Originally, 1,780 firms were identified in the 2005 mapping; of these, 1,230 were found in the

PLACE database. Most of the firms not found were "one-person firms" (i.e., selfemployed

owner/operators), without record of employees. [on p. 255]
} 


\section{LIFE SCIENCE IN SWEDEN: FROM PHARMACEUTICALS TO BIO-TECHNOLOGY}

As the number of life science-oriented firms in Sweden has increased in recent years, the industry has also come to encompass an ever wider variety of activities. A mapping conducted by Vinnova, the Swedish Governmental Agency for Innovation Systems, identifies the bio-technology, pharmaceuticals, and medical technology sectors as potential cornerstones of the Swedish economy (Dolk and Sandström 2007). Although the industry is quite diverse in terms of activity span, many of the constituent companies are indirectly connected with each other. Large life science firms, particularly "big pharma," have, over the years, spun off parts of their operations into new and promising start-ups in sub-industries, such as bio-technology, medical technology, and diagnostics. A number of firms have been formed in the wake of mergers and spin-offs related to the corporate structure of the former multinational Sweden-based pharmaceutical firm Pharmacia, including what are now parts of GE Healthcare, Phadia (formerly Pharmacia Diagnostics), Biovitrum, Biacore, Fresenius Kabi, and Active Biotech - to name a few (see Dahlgren and Valentin 2009; Waxell 2005). In terms of media and policy attention, the industry has attracted increasing interest since the mid-1990s. However, other voices claim that the industry's growth is more a result of a long-standing industrial tradition and history than a phenomenon occurring in the 1990s, as mainly portrayed in the media (see, e.g., Waluszewski 2003).

The life science industry in Sweden is rooted in the pharmaceutical industry, which in turn owes its existence mostly to a few major global firms. Today, the industry incorporates hundreds of firms in various life science-related fields. From a historical perspective, most traditional pharmaceutical firms and the emerging pharmaceutical industry have their roots in the chemical and dye industries, primarily in Germany, Switzerland, and the U.S., including firms such as Bayer, Novartis, Merck Sharp and Dohme, Janssen-Cilag, and Boehringer Ingelheim. Also, many firms around the world originally started as pharmacies (e.g., Shering-Plough, Eli Lilly, and Hässle, Astra, Vitrum, and Pharmacia in Sweden). In the recent years, many life science companies have also emerged in industries linked to the environmental, agricultural, and food sectors. For example, some Swedish firms, such as Kabi, have a history in the brewing industry (Frankelius 1999). However, the major breakthroughs in the Swedish pharmaceutical industry mainly occurred in the 1940s and onwards, with the development of several "blockbuster" products, including Xylocaine, Seloken, Losec (Astra), Macrodex, Sephadex, [end of p. 239] Genotropin (Kabi/Pharmacia), and Gonadex and Nicorette (Leo). In the early 1980s, the five major pharmaceutical firms (i.e., Astra, KabiVitrum, Pharmacia, Leo Ferrosan, and Ferring) represented virtually the entire production of pharmaceuticals in Sweden and nearly half the turnover of pharmaceuticals in the Swedish market (Brandt 1985; Unger 1992). Today, only one of these firms has remained more or less intact until present day, i.e., AstraZeneca.

In recent years, life science has become closely associated with bio-technology. The boundary between conventional pharmaceutical preparation (based on chemical 
synthesis) and product development based on bio-technological processes (proteinbased synthesis) has today been crossed in many ways. This is particularly evident in the many major multinational pharmaceutical firms that increasingly are incorporating and relying on bio-technological processes in their operations (see McCutchen and Swamidass 1996; Prevezer 1998; Zucker and Darby 1997; Zucker, Darby, and Armstrong 1998). Modern bio-technology was introduced as an industrial application on a large scale in the U.S. in the 1970s and 1980s under the leadership of firms, such as Biogen and Genentech. These firms were founded through collaborations and strategic alliances among universities, venture capital firms, and large pharmaceutical firms. This set-up also highlights the importance in the emerging life science industry of being closely connected with the research front and of having access to funders willing to take risks. The use of traditional bio-technology processes in industry has a long history (e.g., using fermentation to produce alcohol, beer, bread, and penicillin) but, with the groundbreaking scientific discoveries of the first half of the 1970s, a new and modern form of bio-technology emerged. The findings were based primarily on the development of recombinant DNA technology (rDNA, often referred to as genetic engineering) and the production of monoclonal antibodies (so-called MABS technology). These technologies have spurred industrial and commercial interest in biotechnology and, as such, have been important in forming the industrial structure of a modern global industry (for more detailed discussion, see Zucker and Darby 1997). One of the first dedicated bio-technology firms in Sweden was KabiVitrum, which in the late 1970s established a close relationship and well-developed collaboration with the U.S.-based firm, Genentech.

The pharmaceuticals industry in Sweden faced a major wave of restructuring in the 1980s and 1990s. Ferrosan was purchased by Leo (1984), which was acquired by Pharmacia (1986), which in the same year merged with LKB Products, which then merged with Upjohn (1995), and was subsequently purchased by Pfizer (2003). Astra merged with Zeneca in 1998 (see Dahlgren and Valentin 2009; Frankelius 1999; Unger 1992; Waxell 2005). Today, the largest pharmaceutical firms in Sweden are AstraZeneca, Pfizer, and Fresenius Kabi. Much of the [end of p. 240] Swedish industrial success in the life science industry can also be traced to Pharmacia and Astra (in different configurations and under various names) as, over the years, they have invested considerable resources in $\mathrm{R} \& \mathrm{D}$, developed and produced plentiful commercially successful products (also in collaboration with the Swedish university sector), and also spun off many activities around the country.

\section{Industry structure}

Today's life science industry is multifaceted and incorporates a variety of activities. Big pharmaceutical firms often tend to be contrasted with small R\&D-intensive firms, often in bio-technology. However, there is research indicating that these firms often benefit from, and complement, each other. For example, many smaller bio-technology firms 
form strategic alliances with larger pharmaceutical firms when they enter a clinical test phase. The larger firms take over funding and responsibility for the often capitalintensive and time-consuming test procedures that follow. Larger pharmaceutical firms may also take over production and marketing functions from smaller bio-tech firms where such channels are missing (Bagchi-Sen 2007; McCutchen and Swamidass 1996).

By the end of 2005, the life science industry in Sweden included 1,230 firms and organisations and employed approximately 53,169 individuals in six interrelated subindustries (Table 1). The life science industry is generally portrayed as consisting of small firms encompassing knowledge- and capital-intensive activities where considerable resources are annually spent on $R \& D$. The study found that most organisations, approximately 55 percent, are small firms in the category

Table 1. Number and proportions of organizations and employees in life science subindustries in 2005.

\begin{tabular}{lrrrr}
\hline \hline & \multicolumn{3}{c}{ Organizations } & \multicolumn{2}{c}{ Employees } \\
\cline { 2 - 6 } Sub-industry & No. & $(\%)$ & No. & $(\%)$ \\
\hline Bio-technology & 143 & $(11.6)$ & 9,751 & $(18.3)$ \\
Pharmaceuticals & 164 & $(13.3)$ & 20,520 & $(38.6)$ \\
Medical technology & 661 & $(53.7)$ & 17,169 & $(32.3)$ \\
Diagnostics & 38 & $(3.1)$ & 1,420 & $(2.7)$ \\
CRO & 43 & $(3.5)$ & 1,879 & $(3.5)$ \\
Miscellaneous & 181 & $(14.7)$ & 2,430 & $(4.6)$ \\
Total & 1,230 & $(100)$ & 53,169 & $(100)$ \\
\hline \hline
\end{tabular}

[end of p. 241] of one to nine employees. Together they employ only 4.7 percent of the individuals in the industry (see Fig. 1). In contrast, around half of individuals included in the data are employed by one of the industry's 12 large firms ( $\geq 500$ employees).

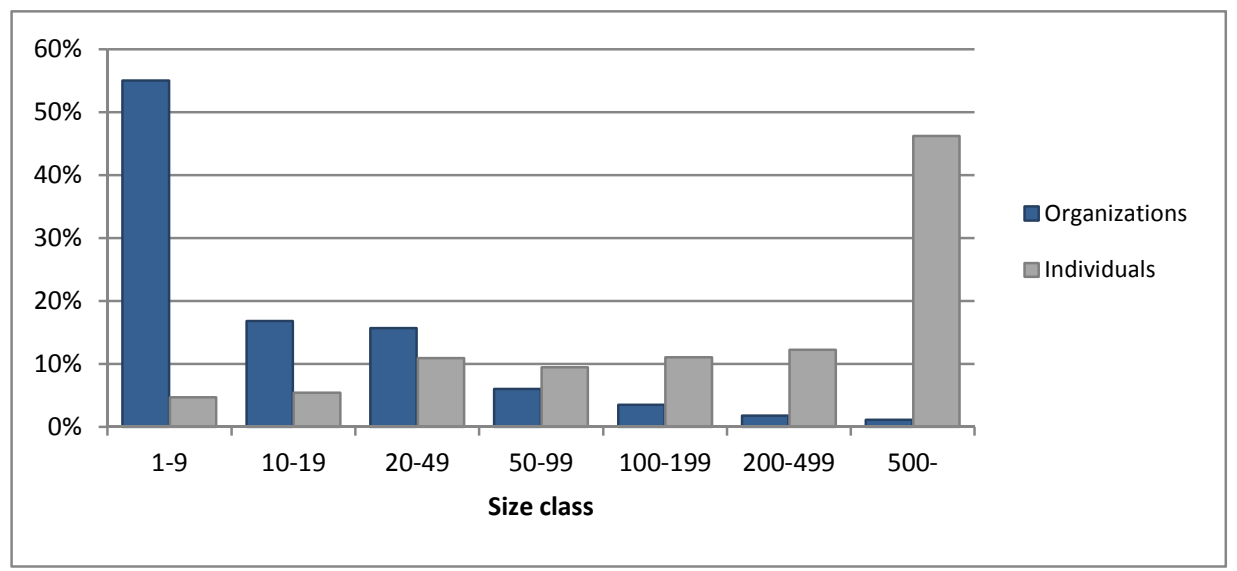

Figure 1. Number of organizations and individuals according to firm size in the life science industry in 2005. 
The largest sub-industry in the life sciences is the pharmaceuticals industry, which employs approximately 20,500 individuals, corresponding to more than every third person in the life sciences. This sub-industry is also dominated by a few large firms having 500 or more employees. Most firms, however, are found in medical technology; these are mainly smaller firms having one to nine employees (Table 1).

\section{Jobless growth}

Though the industry is mostly composed of smaller firms and viewed from an employment perspective, the industry is largely dependent on a few large firms. Over the past 15 years, developments in the Swedish life science industry have involved a number of major mergers and acquisitions in "big pharma." Great attention has been paid to the merger of Pharmacia and Upjohn in 1995, to Pfizer's subsequent takeover of Pharmacia's pharmaceutical operations, and, in particular, to the effects of the ensuing relocation of large parts of the firms for the Uppsala region (see Waluszewski 2003; Waxell 2005). The reliance of the industry on one, or a few, large multinational firms tends to make it more sensitive to changes, for example, in firm strategy and business decisions made at multinational firm headquarters, often located elsewhere. The relocation or termination of, for example, AstraZeneca's activities in Sweden - which in 2005 employed approximately 10,000 people-would significantly alter the industry's employment structure. [end of p. 242]

Table 2. Growth within the stock of organizations active in 2002 and 2005 in the life science industry and in Sweden in total.

\begin{tabular}{lcc}
\hline \hline & Life science & Sweden in total \\
& $\%$ & $\%$ \\
\hline Individuals & $\% .6$ & -5.6 \\
Income & 12.9 & 11.6 \\
\hline \hline
\end{tabular}

From a national perspective, the industry constitutes less than half of 1 percent of all firms and organisations in Sweden. In terms of employment, about one in a hundred people of working age in Sweden are employed by a life science firm. From a labourpolitical perspective, the life science industry constitutes only a small part of the Swedish labour market. Although unemployment in Sweden during the period studies has been relatively high, unemployment in the life science industry has been lower than the national average (see Waxell et al. 2006). If analysing the stock of active firms in the life science industry and in Sweden in total in 2002 and 2005, it is possible to measure and compare growth both in terms of employment and income. ${ }^{4} 4$ According to Table 2,

${ }^{4}$ The static nature of the mapping makes it hard to measure growth over the years. The number of firms identified in the database varies between the years studied, 
the period shows a decrease in the number of individuals employed both within the industry ( -3.1 percent) and in Sweden in total (-5.6 percent), although less negative in the life science industry. However, when comparing income, the table shows a positive trend where income in the life science industry has increased to 12.9 percent, an increase of 1.3 percentage points above the growth rate in Sweden in total. During the years analysed, this would indicate that Sweden, and in particular, the life science industry, has been subject to jobless growth.

Additionally, in terms of jobless growth, it is important to bear in mind that this, in employment terms, relatively small-scale industry is nevertheless important for Sweden's GDP as an export sector. In particular, the pharmaceutical industry has been a heavy export industry since the mid-1980s. The pharmaceutical industry is characterised as capital-intensive and produces a high added value per employee. It is traditionally also one of the industries with the highest $\mathrm{R} \& \mathrm{D}$ expenditures. As a class of goods, pharmaceuticals stand out in comparison with goods from other major Swedish export industries. In 2005, pharmaceuticals accounted for approximately 5.5 percent of Sweden's gross exports and as much as 23 percent of net exports. During a 10-year period, 1995 to 2005, pharmaceutical exports increased by 198 percent. AstraZeneca accounts for a significant share of these exports (Statistics Sweden 2008). [end of p. 243]

\section{Human capital}

To understand how the industry may contribute to growth, other than related to employment growth, it is important to closely examine the composition of the human capital in the industry. In terms of age distribution, it is notable that the industry appears to be composed of "young professionals" (see Table 3). Almost, every third person in the life science industry is 30-39 years old, while a large proportion of the workforce throughout the nation is beginning to move closer to retirement age. For firms in the life sciences, this means that the cohort of individuals aged 30-39 years can stay within the firm for another 20-30 years before they are of retirement age. This observation implies that the firms should be able to nurture the knowledge and skills that exist in the organisation. Another feature of the industry is that there is only a marginal difference between the number of men and women throughout the age cohorts. In other words, the life science industry does not appear to be caught in a rigid structure dominated by men of late middle age.

Table 3 shows that the education level in the life science industry is high. A plurality, 40 percent, has university or college education equivalent to a bachelors or masters degree.

which in turn may provide a false indication of growth or decline. The variation is basically a result of a closer fit between the year of the mapping and subsequent matching in the database for each year. One way of dealing with this problem is to analyse growth within organisations active throughout the period studied (i.e., in the stock of organisations). This will provide a sufficient picture of the direction in which the industry is developing. [on p. 255] 
A distinctive feature of the industry is the high proportion of researchers and scientists. Approximately 7 percent have a doctoral degree, which can be compared with the national average of only 1 percent; however, it should be noted that in the industry, this category is overrepresented by men. In contrast, more women have a post-secondary education of more than 2 years (e.g., bachelor's- and master's-level educations). The most knowledge-intensive sub-industries, in terms of share of doctoral degrees, are diagnostics, pharmaceuticals, and miscellaneous (often consultancy-based research firms). In addition, most of the workforce is university or college educated in nearly all sub-industries, except for medical technology, in which a higher proportion of the workforce is lower educated.

Using a knowledge and skills-based approach to human capital, it is also of interest to examine what types of education are most common in the industry. Following Statistics Sweden's classification at a two-digit level, which is relatively coarse, and according to Table 4, the most common education levels are basic and general education. This category primarily consists of compulsory education and secondary education (up to 3 years). Among the more specialised education programmes, the most common are oriented towards business administration and commerce, followed by programmes emphasising chemistry and process. Although the industry is relatively broadly defined, most popular education programmes are found among those with a personnel focus on technology and life science-oriented areas. However, the high percentage of economyrelated educations is not surprising, as administrative and finance-related tasks, such as purchasing, sales, and accounting, are essential to the daily management of firms. [end of p. 244] 
Table 3. Age distribution, education, and income level by gender in the life science industry and in Sweden in year 2005.

\begin{tabular}{|c|c|c|c|c|c|c|}
\hline & \multicolumn{4}{|c|}{ Life science industry } & \multicolumn{2}{|c|}{ Sweden, total } \\
\hline & Men & Women & Total & Men & Women & Total \\
\hline \multicolumn{7}{|l|}{ Age distribution* } \\
\hline 16-29 & $23.3 \%$ & $22.2 \%$ & $22.8 \%$ & $25.5 \%$ & $25.9 \%$ & $25.7 \%$ \\
\hline $30-39$ & $32.4 \%$ & $33.3 \%$ & $32.8 \%$ & $24.2 \%$ & $23.4 \%$ & $23.8 \%$ \\
\hline $40-49$ & $22.6 \%$ & $23.3 \%$ & $22.9 \%$ & $21.7 \%$ & $22 \%$ & $21.8 \%$ \\
\hline $50-64$ & $21.6 \%$ & $21.2 \%$ & $21.4 \%$ & $28.7 \%$ & $28.7 \%$ & $28.7 \%$ \\
\hline Total & $100 \%$ & $100 \%$ & $100 \%$ & $100 \%$ & $100 \%$ & $100 \%$ \\
\hline \multicolumn{7}{|l|}{ Education level } \\
\hline Post-graduate programmes & $8.5 \%$ & $5.0 \%$ & $6.7 \%$ & $1.3 \%$ & $0.7 \%$ & $1.0 \%$ \\
\hline Post-secondary education more than two years & $36.8 \%$ & $44,4 \%$ & $40.6 \%$ & $21.3 \%$ & $31.6 \%$ & $26.3 \%$ \\
\hline Post-secondary education less than two years & $10.4 \%$ & $6.3 \%$ & $8.3 \%$ & $7.3 \%$ & $5.4 \%$ & $6.4 \%$ \\
\hline Upper secondary education & $35.4 \%$ & $34.9 \%$ & $35.1 \%$ & $48.6 \%$ & $46.4 \%$ & $47.5 \%$ \\
\hline Compulsory education ( 9.10 years) & $6.9 \%$ & $7.3 \%$ & $7.1 \%$ & $13.9 \%$ & $11.2 \%$ & $12.6 \%$ \\
\hline Primary education ( $<9$ years) & $1.6 \%$ & $1.8 \%$ & $1.7 \%$ & $6.0 \%$ & $3.8 \%$ & $5.0 \%$ \\
\hline Unknown & $0.6 \%$ & $0.3 \%$ & $0.4 \%$ & $1.6 \%$ & $0.9 \%$ & $1.3 \%$ \\
\hline Total & $100 \%$ & $100 \%$ & $100 \%$ & $100 \%$ & $100 \%$ & $100 \%$ \\
\hline \multicolumn{7}{|l|}{ Income level (SEK) } \\
\hline Mean & 394,000 & 285,000 & 339,000 & 247,000 & 174,000 & 211,000 \\
\hline Q25 & 247,000 & 178,000 & 211,000 & 121,000 & 72,000 & 93,000 \\
\hline Median & 338,000 & 271,000 & 302,000 & 241,000 & 176,000 & 207,000 \\
\hline Q75 & 470,000 & 363,000 & 417,000 & 319,000 & 244,000 & 285,000 \\
\hline
\end{tabular}

* Data for the year 2002. SEK, Swedish krona.

[end p. 245]

Table 4. Ten most common types of education in the life science industry in 2005.

\begin{tabular}{lcc}
\hline \hline \multirow{2}{*}{ Education } & \multicolumn{2}{c}{ Life science industry } \\
\cline { 2 - 3 } & No. & $(\%)$ \\
\hline Basic/broad general programmes & 8,604 & $(16.2)$ \\
Business and administration & 5,373 & $(10.1)$ \\
Chemical and process & 3,624 & $(6.8)$ \\
Mechanics and metal work & 2,866 & $(5.4)$ \\
Electronics and automation & 2,400 & $(4.5)$ \\
Medical diagnostic and treatment technology & 2,315 & $(4.4)$ \\
Nursing and caring & 2,247 & $(4.2)$ \\
Engineering and engineering trades & 2,235 & $(4.2)$ \\
Chemistry & 2,006 & $(3.8)$ \\
Medicine & 1,396 & $(2.6)$ \\
\hline \hline
\end{tabular}


In addition, by examining the occupational structure, we can learn more about the nature of the human capital in the industry. Much of the knowledge and skills possessed by individuals is acquired at the workplace (see Lucas 1988). Not surprisingly, the life science industry comprises many types of occupations. ${ }^{5}$ All in all, most job opportunities, where known, are found in the occupational category of physical and engineering science technicians, closely followed by occupations in finance and sales as well as related engineering occupations (see Table 5). As a complement to the educational focus, this presents a fairly coherent image of the structure and characteristics of the human capital in the life science industry. Notably, the industry is largely dominated by individuals with technical training and in engineering professions, and not with medical training and in related occupations. Furthermore, it is also noteworthy that educations and professions related to business and administration are an integral and important part of the industry.

An additional way to examine the importance of human capital is to measure and compare income levels. Compared with the rest of Sweden's economy, income levels in the life science industry are well above the national average. ${ }^{6}$ In 2005 , the median income in the life science industry was Swedish krona (SEK) 302,000, while the national median amounted to SEK 207,000. One in four individuals in the industry earns an annual income above SEK 417,000 (see Table 3). While the industry exhibits a relatively equal gender balance as regards [end of p. 246]

Table 5. Ten most common occupations in the life science industry in 2002 (rank indicated in parentheses).

\begin{tabular}{lcc}
\hline \hline & Life science & Sweden in total \\
\cline { 2 - 3 } Occupation & $\%($ rank $)$ & $\%($ rank $)$ \\
\hline Occupation unknown & $8.0(1)$ & $5.6(2)$ \\
Physical and engineering science technicians & $7.7(2)$ & $3.3(5)$ \\
Finance and sales associate professionals & $7.5(3)$ & $4.1(4)$ \\
Architects, engineers, and related professionals & $7.5(4)$ & $1.2(22)$ \\
Physicists, chemists, and related professionals & $5.5(5)$ & $0.2(82)$ \\
Chemical-processing-plant operators & $5.3(6)$ & $0.2(81)$ \\
Other specialist managers & $5.1(7)$ & $1.6(20)$ \\
Administrative associate professionals & $4.6(8)$ & $1.9(14)$ \\
Chemical-products machine operators & $4.5(9)$ & $0.3(68)$ \\
Business professionals & $3.4(10)$ & $2.2(9)$ \\
\hline \hline
\end{tabular}

5 The occupational categories used here are based on the Swedish Standard Classification of Occupations (SSYK 96). This conforms to the International Standard Classification of Occupations 1988 (ISCO) and the EU standard ISCO-88(COM). [on p. 256]

${ }^{6}$ The income level is related to the largest income source (i.e., earnings before tax and or business income) during the year studied (see LOUISE-manua 1, Statistics Sweden 2002). [on p. 256] 
employment opportunities, there are apparent disparities between male and female labour: men earn more, have more doctorates, and are less likely to be unemployed or underemployed than are women (see also Waxell et al. 2006). Although the median income level of women in the life science industry is still well above the national average, women have lower incomes than do men in the industry. This is partly because of gender differences in educational approaches, because more men have doctoral degrees, and because more women are not fully employed year-round. In terms of education, men are more oriented towards technology-related areas (e.g., machinery, engineering, electronics, data, and other industrial technology applications), while women are more oriented towards economics, chemistry and process, health care, and nursing. These differences are also reflected in occupational characteristics. Many men work as engineers or technicians, while it is more common for women to work as accountants, administrative assistants, or in sales and purchasing.

High levels of education and income strongly support the image of the life science industry as knowledge-intensive. The availability of well-educated individuals can be expected to provide an attractive basis for the workforce, while high income levels reflect the industry's willingness to pay well for the skills needed (see Power and Lundmark 2004). The proportion of foreign-born personnel is also higher in the industry compared with the national average. According to a study of the bio-tech cluster in Uppsala (Waxell 2005), a large proportion of individuals [end of p. 247] born outside Sweden and working in the cluster have doctoral degrees. This suggests that the life science industry also has the ability to source highly educated personnel from around the world.

\section{Geography and specialisation}

Although the life science industry is a global industry with a relatively mobile workforce, especially in the scientific community, it has been demonstrated that the industry is largely concentrated and often rooted in local or regional industrial or research-related milieus (Audretsch and Stephan 1996; Lowe and Gertler 2005; McKelvey, Alm, and Riccaboni 2003; Zucker, Darby, and Armstrong 1998; Zucker, Darby, and Brewer 1998). The location of public research facilities is thus a basic factor stimulating new firm formation and the relocation of firms related to the life science industry. This is partly because many business founders in this industry themselves have roots in academia and also because there is ongoing need for firms to be connected with research networks in world-leading university milieus, so that they can obtain otherwise unavailable knowledge. The role of universities is also multidimensional because they often act as important providers of labour, materials, research, equipment, and laboratories. Moreover, they are also important as customers and business partners (Prevezer 1998; Waxell 2005; Waxell and Malmberg 2007).

This geographical pattern is also evident in Sweden. The industry is mainly concentrated in the metropolitan regions of Stockholm-Uppsala, Malmö-Lund (and the Öresund 
region), and Gothenburg. Life science activities are also found, albeit to a lesser extent, in the Umeå and Linköping regions (see Figure 2). In other words, the industry is concentrated in regional clusters across the country but is essentially rooted in the Stockholm region, which houses nearly half (48

percent) of all firms in the industry and 44 percent of the employees. Stockholm and Uppsala, which are included in the so-called Mälardalen region, together dominate the industry in terms of number of both firms and workers.

Large metropolitan regions themselves act as a strong force attracting both individuals and firms wanting to choose new locations. Locating economic activities in larger cities offers numerous advantages. These centres often possess flexible labour markets, can provide access to established business networks, and are often home to industrial structures and entrepreneurial opportunities for activities specialising in the microelectronics, bio-technology, software engineering, specialised business services, financial services, and cultural industries. Available work tasks tend to be more advanced and cognitive in the larger cities, while more labour-intensive activities (e.g., in manufacturing industries) tend to be more spatially distributed and are more likely to be located in smaller cities (Scott 2009). Over the years, in Sweden, infrastructure has come to shape a locally [end of p. 248] 

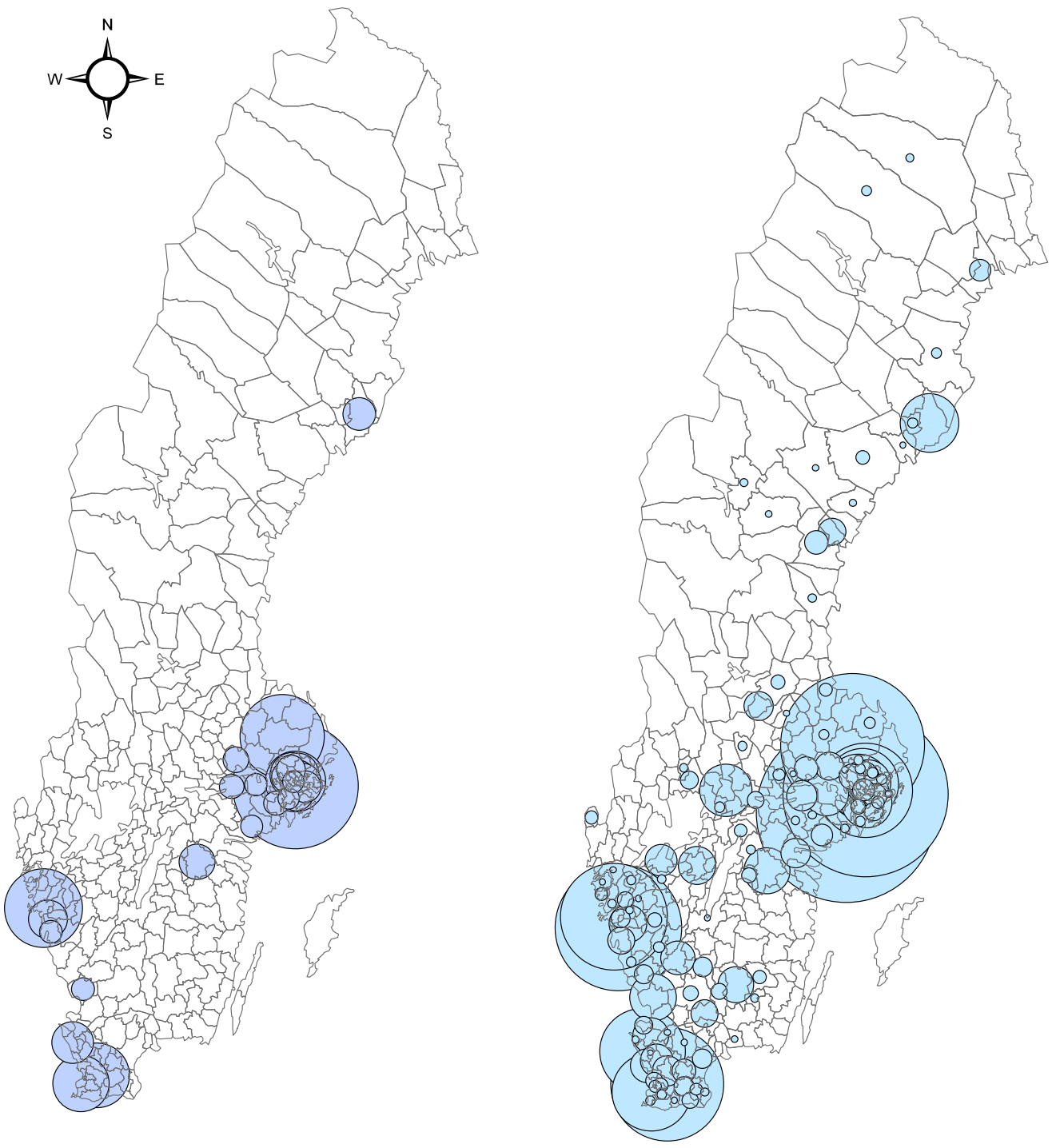

No. of employees (>= 10)

No. of workplaces $(>=10)$
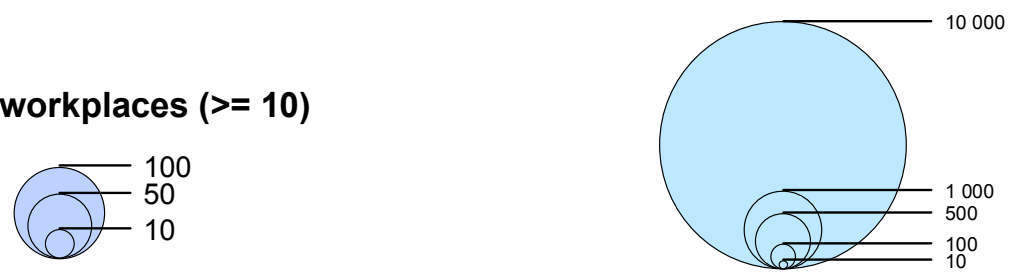

Figure 2. Number of workplaces and employees in the life science industry (10 or more) in Swedish municipalities in 2005.

[end of p. 249] 
rooted knowledge-base in several life science-related fields located particularly in university towns and metropolitan areas hosting major universities.

This specialisation has a clear geographical dimension (see Table 6). The sub-industry of pharmaceuticals, which in terms of number of employees includes the largest firms, is mainly concentrated in the Stockholm and Gothenburg regions. This is largely explained by the local presence of multinational pharmaceutical firms, such as AstraZeneca and Pfizer. Bio-technology, on the other hand, is dominant in the Uppsala region and in Umeå. In Uppsala, the collaboration between Uppsala University and the former Pharmacia corporation in the 1940s and 1950s exerted great influence on how the competence structure of the contemporary bio-tech cluster in Uppsala was formed. The emphasis here has been on the development of bio-technological methods, tools, and research instruments, an emphasis that has ultimately come to distinguish Uppsala from Stockholm (see Waxell 2005). In Östergötland, in the "other regions" category, and even in the Malmö region, it is more common to work in a medical technology firm. The Malmö region is also the one with the widest distribution of employees spanning the various sub-industries.

The geographical pattern presents a clear pattern as concerns education and income levels. It may furthermore be assumed that the preconditions for firms in the industry to source needed knowledge and skills are better in regions with high education and income levels. The regional setting thus helps foster and nurture locally embedded human capital. According to the empirical material, education levels are generally highest in the larger metropolitan areas, and in the regions of Uppsala and Östergötland. The lowest levels are found among employees in the Umeå region and in the category including other regions in Sweden. Over half the workforce in these regions possesses only secondary education. It may also be assumed that the major employers in these regions are more oriented towards manufacturing. Furthermore, proximity to major universities promoting life science-oriented research is more pronounced in the larger metropolitan areas, Uppsala, and the Östergötland region than in other regions of the country.

The income distribution data indicate a geographical pattern similar to that of education. However, with a median income of SEK 326,000, the Uppsala region is at par with the Stockholm region in the top. The lowest income and education levels are found in Umeå and the "other regions" category (see Table 7). Moreover, if the income level is further geographically divided into municipalities, the geographical pattern describing income levels becomes even more nuanced (see Figure 3).

In conclusion, the high education levels in the life science industry suggest that the industry is indirectly dependent on a strong academic base and that proximity [end of p. 251] 
Table 6. Geographical distribution of individuals in sub-industries of the life science industry in 2005.

\begin{tabular}{|c|c|c|c|c|c|c|c|c|c|}
\hline \multirow[b]{3}{*}{ Bio-technology } & \multicolumn{9}{|l|}{ Region } \\
\hline & \multicolumn{2}{|c|}{ Stockhol Gothenburg } & \multirow{2}{*}{$\begin{array}{l}\text { Malmö } \\
2,534\end{array}$} & \multirow{2}{*}{$\begin{array}{r}\text { Uppsala } \\
3,040\end{array}$} & \multirow{2}{*}{$\begin{array}{r}\text { Östergötland } \\
64\end{array}$} & \multirow{2}{*}{$\begin{array}{r}\text { Umeå } \\
579\end{array}$} & \multirow{2}{*}{$\begin{array}{r}\text { Other regions } \\
458\end{array}$} & \multirow{2}{*}{$\begin{array}{r}\text { Unknown } \\
33\end{array}$} & \multirow{2}{*}{$\begin{array}{l}\text { Total } \\
9751\end{array}$} \\
\hline & 2,655 & 388 & & & & & & & \\
\hline Pharmaceuticals & 13,040 & 3,558 & 2,322 & 319 & * & 258 & 579 & 442 & 20,520 \\
\hline $\begin{array}{l}\text { Medical } \\
\text { technology }\end{array}$ & 5,747 & 3,088 & 3,231 & 948 & 650 & 25 & 3,408 & 72 & 17,169 \\
\hline Diagnostics & 356 & 171 & 139 & 735 & * & 11 & 8 & * & 1420 \\
\hline CRO & 632 & 116 & 87 & 287 & 56 & 9 & 436 & 256 & 1879 \\
\hline Miscellaneous & 879 & 627 & 238 & 271 & 60 & 31 & 316 & 8 & 2430 \\
\hline Total & 23,309 & 7,948 & 8,551 & 5,600 & 832 & 913 & 5,205 & 811 & 53,169 \\
\hline
\end{tabular}

${ }^{*}$ Fewer than five individuals.

CRO, contract research organisation.

[end of p. 251]

Table 7. Regional income distribution (SEK) in the life science industry in 2005.

\begin{tabular}{lcccc}
\hline \hline Region & Mean & Q25 & Median & Q75 \\
\hline Stockholm & 365 & 239 & 326 & 446 \\
Gothenburg & 372 & 202 & 307 & 434 \\
Malmö & 311 & 197 & 282 & 387 \\
Uppsala & 349 & 229 & 326 & 431 \\
Östergötland & 289 & 167 & 289 & 387 \\
Umeå & 244 & 183 & 255 & 301 \\
Other regions & 255 & 167 & 247 & 312 \\
Total & 211 & 12 & 52 & 361 \\
Unknown & 339 & 211 & 302 & 417 \\
\hline \hline
\end{tabular}

SEK, Swedish krona.

to universities is important. Human capital can thus be viewed as a core resource for more research-intensive firms. Life science research is largely multidisciplinary or crossdisciplinary, and only in recent decades have life science-oriented education and research programmes become increasingly popular in Swedish universities and colleges. To be part of the research front, cross-disciplinary research collaborations, particularly in medicine and biosciences, are essential. Universities will therefore play a key role in stimulating research that is relevant to innovation processes in the life science industry, and as providers of educated people ready to meet the personnel demands of the industry. 


\section{CONCLUDING DISCUSSION}

Globalisation and the use of new communication technologies are bringing the world closer together and intensifying economic competition. In this process, technology and access to knowledge and skills have become ever more important. In Sweden, this has led to changing conditions in the labour market, leading to increasing demand for highly skilled and specialised labour. As knowledge-intensive and high-tech activities have increased in prominence, there has been considerable policy interest in the life science industry, particularly in biotechnology, pharmaceuticals, and medical technology.

This study analyses various structural aspects and the potential of the life science industry in Sweden to act as a driver of industrial transformation and growth. Specific attention has been paid to investigating human capital in this [end of p. 252]

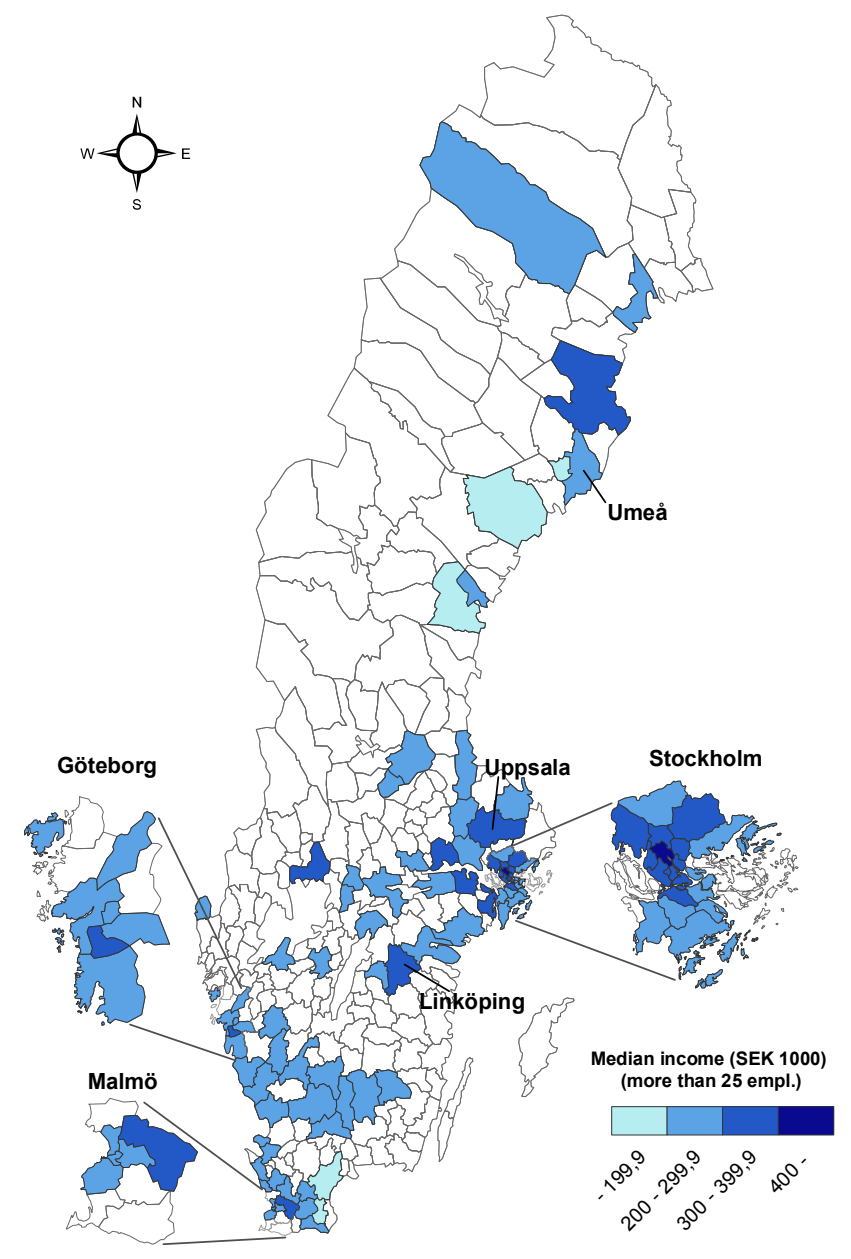

Figure 3. Median income distribution in Swedish municipalities having more than 25 employees in the life science industry in 2005.

[end of p. 253] 
industry in comparison with that of the nation as a whole. Mapping the Swedish life science industry reveals that the industry itself is relatively small in terms of number of both firms and, particularly, employees. Although the life science industry is broadly defined here, only one in a hundred people in Sweden's total workforce was employed by a life science firm in 2005 .

Considerable industrial policy interest has been directed towards the biotechnology industry in particular. However, this study demonstrates that biotechnology, as a subindustry, represents only 11.6 percent of the total number of firms in the life science industry and employs only one-fifth of the industry's total workforce. More importantly, the study also demonstrates that the industry's employment is largely dependent on a few large firms, particularly multinationals oriented towards pharmaceuticals. Nearly half of the life science workforce is employed by 12 of the largest firms in the industry. In other words, the industry, as such, should not be regarded as a future and major growth engine expected to create a vast number of job opportunities. Although the life science industry shows low unemployment numbers, it is more likely that growth in the industry will be "jobless." However, this does not mean that the industry is not to be regarded as a growth industry in other respects, for example, in form of human capital and especially in terms of education and income. However, it should be noted that the industry does contribute to growth in other ways, primarily as an important exporting industry. In this context, the pharmaceutical industry plays a central role, as pharmaceutical products accounted for as much as 23 percent of Sweden's net exports in 2005. These figures and future development, however, are heavily dependent on the success and tribulations of a few large firms, such as AstraZeneca.

The industry's potential is likely better suited to contributing to growth in other respects rather than regular employment growth. This becomes evident when studying the structure and characteristics of the human capital embedded in the life science industry. Looking at both education and income levels, it is apparent that the industry is highly knowledge-intensive and that its human capital is in heavy demand. More than 38 percent of its personnel are highly educated and have two or more years of college or university experience, and approximately 6 percent have completed post-graduate studies. Income levels of employees in the industry are also well above the national average.

It should also be concluded that the industry displays distinct patterns of both regional concentration and specialisation, laying the groundwork for dynamic, local labour markets. Regions in Sweden are more or less specialised in one of the sub-industries of the life sciences. The industry is primarily located in major cities, but also in university towns. Relational and spatial proximity between [end of p. 254] academia and industry is one of the industry's strongest characteristics. The industry also presents clear regional differences in education and income levels. 
In summary, the life science industry exhibits a distinct regional concentration, where proximity to university milieus is particularly crucial. The proximity to universities is reflected by high education and income levels and low unemployment rates (see also Waxell et al. 2006). Human capital can thus be regarded as a key resource for many life science firms. The industry's importance for national economic growth is also obvious, as its relatively small workforce produces a large proportion of Sweden's net exports. Finally, it should be noted that firms in life science-related industries are the focus of this study.

However, further studies are needed, and to evaluate the relevance of life sciences to the national or regional economy, it is important to view life science from a holistic perspective and thus as a sector or cluster. In addition to firms, and as a cluster, life science activities should also include public and private research organisations, parts of the health-care sector, venture capital firms, and other specialised and complementary activities with a life science focus. If one takes all these activities into account, the magnitude of the sector/cluster would increase considerably, in terms of number of both organisations and employees. However, these activities are difficult to capture and identify using traditional industrial classifications and official statistics. More studies are thus needed in which life science-related activities, or any industrial activities for that matter, are systematically examined and categorised based on an industrial systemsinspired approach to industrial transformation and growth.

\section{REFERENCES}

Acs, Z.J., D.B. Audretsch, and M.P. Feldman. 1994. Research-and-development spillovers and recipient firm size. Review of Economics and Statistics 76(2): 336-340.

Almeida, P., and B. Kogut. 1999. Localization of knowledge and the mobility of engineers in regional networks. Management Science 45(7): 905-917.

Audretsch, D.B. 2001. The role of small firms in US biotechnology clusters. Small Business Economics 17(1-2): 3-15.

Audretsch, D.B., and P.E. Stephan. 1996. Company-scientist locational links: The case of biotechnology. American Economic Review 86(3): 641-652.

Bagchi-Sen, S. 2007. Strategic considerations for innovation and commercialization in the US biotechnology sector. European Planning Studies 15(6): 753-766.

Baily, M.N., and R.Z. Lawrence. 2004. What happened to the great US job machine? The role of trade and electronic offshoring. Brookings Papers on Economic Activity 2: 211-284.

Barney, J. 1991. Firm resources and sustained competitive advantage. Journal of Management 17(1): 99-120.

Becker, G.S. 1962. Investment in human capital: A theoretical analysis. Journal of Political Economy 70(5): 9-49.

Bhalotra, S.R. 1998. The puzzle of jobless growth in Indian manufacturing. Oxford Bulletin of Economics and Statistics 60(1): 5-32. 
Blumenthal, D., N. Causino, E. Campbell, and K.S. Louis. 1996. Relationships between academic institutions and industry in the life sciences:An industry survey. New England Journal of Medicine 334(6): 368-373.

Brandt, E. 1985. Kemisektorn. In Sveriges industriförbund, Sveriges industri, ed. E. Brandt, 291-303. Stockholm: Industriförb.

CEC. 2002. Life sciences and biotechnology: A strategy for Europe. Luxembourg: Commission of the European Communities.

Coenen, L., J. Moodysson, and B.T. Asheim. 2004. Nodes, networks and proximities: On the knowledge dynamics of the Medicon Valley biotech cluster. European Planning Studies 12(17): 1003-1018.

Combes, P.-P., and G. Duranton. 2006. Labour pooling, labour poaching, and spatial clustering. Regional Science and Urban Economics 36(1): 1-28.

Cooke, P. 2002. Biotechnology clusters as regional, sectoral innovation systems. International Regional Science Review 25(1): 8-37.

Cooke, P., and K. Morgan. 1998. The Associational economy: Firms, regions, and innovation. Oxford: Oxford University Press.

Cooke, P., M.G. Uranga, and G. Etxebarria. 1997. Regional innovation systems: Institutional and organisational dimensions. Research Policy 26(4-5): 475-491.

Dahlgren, H., and F. Valentin. 2009. Shaken, not stirred: The re-combinatorial capacity of high-tech regions redeployment of resources released from the downsizing of a lead pharmaceutical firm. Industry and Innovation 16(1): 33-58.

Dahmén, E. 1980. Hur studera industriell utveckling? In Industriell utveckling i Sverige: Teori och verklighet under ett sekel. Uppsatser till ett IUI-symposium i anledning av Marcus Wallenbergs 80-årsdag i Saltsjöbaden, Grand Hotel, den 8-9 oktober 1979, ed. E. Dahmén, and G. Eliasson, 25-62. Stockholm: Industriens Utredningsinstitut; Almqvist \& Wiksell International.

Dasgupta, S., and A. Singh. 2005. Will services be the new engine of Indian economic growth? Development and Change 36(6): 1035-1057.

Deeds, D.L., and C.W.L. Hill. 1996. Strategic alliances and the rate of new product development: An empirical study of entrepreneurial biotechnology firms. Journal of Business Venturing 11(1): 41-55.

DeMartino, R., D.M. Reid, and S.C. Zygliodopoulos. 2006. Balancing localization and globalization: Exploring the impact of firm internationalization on a regional cluster. Entrepreneurship \& Regional Development 18(1): 1-24.

Dibner, M.D. 1986. Biotechnology in Europe. Science 232(4756): 1367-1372.

Dolk, T., and A. Sandström. 2007. National and regional cluster profiles: Companies in biotechnology, pharmaceuticals and medical technology in Sweden 2004. VINNOVA Analys VA 2007:4. Stockolm: VINNOVA-Verket för Innovationssystem (Swedish Agency for Innovation Systems).

DS 2007:48. 2007. Lissabonfördraget. D. 1. Ds: departementsserien, 2007:48. Stockholm: Statsrådsberedningen Fritze.

Eliasson, G., and Å. Eliasson. 1997. The pharmaceutical and biotechnological competence bloc and the development of Losec. In Technological systems and industrial dynamics, ed. B. Carlsson, 139-168, Boston, MA/London: Kluwer Academic.

Ernst \& Young. 2007. Beyond borders: Ernst \& Young's global biotechnology report 2007. London: Ernst \& Young.

Feldman,M. 2003. The location dynamics of the US biotech industry: Knowledge externalities and the anchor hypothesis. Industry and Innovation 10(3): 311-328. 
Feldman, M.P., and R. Florida. 1994. The geographic sources of innovation: Technological infrastructure and product innovation in the United States. Annals of the Association of American Geographers 84(2): 210-229.

Frankelius, P. 1999. Företagande över tid. Vol. 2, Pharmacia \& Upjohn: Erfarenheter från ett världsföretags utveckling. Jönköping/Malmö, Sweden: Internationella handelshögsk/Liber Ekonomi.

Gertler, M.S. 2003. Tacit knowledge and the economic geography of context, or the undefinable tacitness of being (there). Journal of Economic Geography 3(1): 75-99.

Henry, N., and S. Pinch. 2000. Spatialising knowledge: Placing the knowledge community of Motor Sport Valley. Geoforum 31: 191-208.

Jaffe, A.B. 1989. Real effects of academic research. The American Economic Review 79(5): 957-970

Johnreden, A.-C., and H. Tydén. 2005. Utvecklingen av bioteknikbranschen i Sverige. Ura 2005:3. Stockholm: Arbetsmarknadsstyrelsen.

Klofsten, M., and D. Jones-Evans. 1996. Stimulation of technology-based small firms:A case study of university-industry cooperation. Technovation 16(4): 187-193.

Lee, Y., and R. Gaertner. 1994. Technology transfer from university to industry: A large-scale experiment with technology development and commercialization. Policy Studies Journal 22(2): 384-399.

Lowe, N., and M.S. Gertler. 2005. Diversity and the evolution of a life science innovation system: The Toronto region in comparative perspective. In Global networks and local linkages: The paradox of clusters in an open economy, ed. D.Wolfe, andM. Lucas, 25-55. Montreal, QC and Kingston, ON: McGill-Queen's University Press.

Lucas, R.E. 1988. On the mechanics of economic development. Journal of Monetary Economics 22(1): 3-42.

Lundvall, B.-Å. (red.) (1992). National systems of innovation: Towards a theory of innovation and interactive learning. London: Pinter.

Magnusson, L. 1999. Den tredje industriella revolutionen. Stockholm: Prisma/Arbetslivsinstitutet.

Magnusson, L. 2006a. Håller den svenska modellen? Arbete och välfärd i en globaliserad värld. Stockholm: Norstedts akademiska förlag.

Magnusson, L. 2006b. Kreativa job-Nyckel till tillväxt inom tjänstesektorn. Tillväxtpolitisk utblick, 2006:3. Östersund, Sweden: Institutet för tillväxtpolitiska studier (ITPS).

Malmberg, A. 1998. Den gäckande agglomerationsfördelen: Teoretiska principer och empiriska paradoxer. Svensk Geografisk Årsbok 74: 110-124.

Malmberg, A., and P. Maskell. 2002. The elusive concept of localization economies: Towards a knowledge-based theory of spatial clustering. Environment and Planning A 34(3): 429-449.

Mankiw, N.G., D. Romer, and D.N. Weil. 1992. A contribution to the empirics of economic growth. Quarterly Journal of Economics 107(2): 407-437.

Mansfield, E. 1995. Academic research underlying industrial innovations: Sources, characteristics and financing. Review of Economics and Statistics 77(1): 55-62.

Marshall, A. (1920/1960).Industrial organization, continued. The concentration of specialized industries in particular localities. In Principles of economics, book IV: The agents of production, land, labour, capital and organization. Chapter X, ed. A. Marshall, 267-277. London: Macmillan.

Maskell, P., and A. Malmberg. 1999. Localised learning and industrial competitiveness. Cambridge Journal of Economics 23(2): 167-185. 
Mattsson, H. 2007. Mobile talent or privileged sites? Making sense of biotech knowledge worker mobility and performance in Sweden. Social Geography 2: 115123.

McCutchen, W.W.J., and P.M. Swamidass. 1996. Exploring larger biotech research firm strategies: Projections from a comparison of small and larger firms. Technological Forecasting and Social Change 51: 173-184.

McKelvey, M., H. Alm, and M. Riccaboni. 2003. Does co-location matter for formal knowledge collaboration in the Swedish biotechnology-pharmaceutical sector? Research Policy 32: 483-501.

Nutek. 2006. Årsbok 2006: fler nya företag, fler växande företag, fler starka regioner. Stockholm: Verket för näringslivsutveckling (Nutek).

OECD. 2007. Globalisation and regional economies: Can OECD regions compete in global industries? OECD Reviews of Regional Innovation. Paris: OECD.

OECD Observer. 1999. Biotechnology and industry: A union of promise. OECD Observer, March 1999, 216.

Onaran, O. 2008. Jobless growth in the Central and East European countries. Eastern European Economics 46(4): 90-115.

Peck, J., and N. Theodore. 2007. Flexible recession: The temporary staffing industry and mediated work in the United States. Cambridge Journal of Economics 31(2): 171-192.

Penrose, E.T. 1959. The theory of the growth of the firm. Oxford: Basil Blackwell.

Porter, M.E. 1990. The competitive advantage of nations. London: Macmillan.

Porter, M.E. 2000. Locations, clusters, and company strategy. In The Oxford handbook of economic geography, ed. M. Feldman, M.S. Gertler, and G.L. Clark, 253-274. Oxford/New York: Oxford University Press.

Powell,W.W., K.W. Koput, J.I. Bowie, and L. Smith-Doerr. 2002. The spatial clustering of science and capital: Accounting for biotech firm-venture capital relationships. Regional Studies 36(3): 291-305.

Power, D., and M. Lundmark. 2004. Working through knowledge pools: Labour market dynamics, the transference of knowledge and ideas, and industrial clusters. Urban Studies 41(5/6): 1025-1044.

Prevezer, M. 1998. Clustering in biotechnology in the USA. In The dynamics of industrial clustering: International comparisons in computing and biotechnology, ed. P.G.M. Swann, M. Prevezer, and D. Stout, 124-193. Oxford: Oxford University Press.

Rothaermel, F.T., S.D. Agung, and L. Jiang. 2007. University entrepreneurship: A taxonomy of the literature. Industrial and Corporate Change 16: 691-791.

Schultz, T.P. 1995. Human capital and economic development. In Agricultural competitiveness: Market forces and policy choice. Proceedings of the twenty-second international conference of agricultural economists, held at Harare, Zimbabwe, 22-29 August, 1994, ed. G.H. Peters, and D.D. Hedley, 523-539. Farnham: Ashgate Publishing.

Scott, A.J. 2009. Human capital resources and requirements across the metropolitan hierarchy of the USA. Journal of Economic Geography 9(2): 207-226.

SIND. 1991. Biotekniken i svensk industri: bokslut och prognos inför 90-talet. Sind, 1991: 5. Stockholm: Statens industriverk, Allmänna förl.

Statistics Sweden. 2002. En longitudinell databas kring utbildning, inkomst och sysselsättning (LOUISE) 1990-1999. 2002:2. Örebro, Stockholm: Statistiska centralbyrån (SCB).

Statistics Sweden. 2008. Statistisk årsbok för Sverige 2008. Stockholm: Statistiska centralbyrån. 
Stephan, P.E., D.B. Audretsch, and R. Hawkins. 2000. The knowledge production function: Lessons from biotechnology. International Journal of Technology Management 19(1-2): 165-178.

Storper, M., and A.J. Venables. 2004. Buzz: Face-to-face contact and the urban economy. Journal of Economic Geography 4(4): 351-370.

Thrift, N., and A. Amin. 1994. Globalization, institutions, and regional development in Europe. Oxford, New York: Oxford University Press.

Unger, J. 1992. Kemisk industri. In Sveriges industriförbund, Sveriges industri, ed. J. Unger, 227-242. Stockholm: Sveriges industriförb.

Waluszewski, A. 2003. Ur Pharmacias aska reste sig ingen Fågel Fenix. Axess 3(2): 2528.

Waters, R., and H. Lawton Smith. 2008. Social networks in high-technology local economies: The cases of Oxfordshire and Cambridgeshire. European Urban and Regional Studies 15(1): 21-37.

Waxell, A. 2005. Uppsalas biotekniska industriella system: en ekonomisk-geografisk studie av interaktion, kunskapsspridning och arbetsmarknadsrörlighet. Geografiska regionstudier, 62. Uppsala, Sweden: Department of Social and Economic Geography/Kulturgeografiska institutionen.

Waxell, A. 2009. To capture an emerging industry: Using industrial standards to identify the biotech industry. International Journal of Social Research Methodology 12(5): 441-456. 